\title{
An Analysis of the Tragedy in The Catcher in the Rye
}

\author{
JING Jing \\ Changchun University, Changchun, China
}

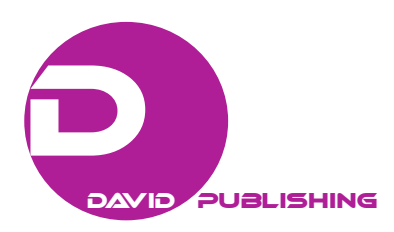

\author{
JING Xia \\ No. 20 Junior Middle School of Siping, Siping, China
}

\begin{abstract}
Jerome David Salinger is a famous American novelist. His famous novel The Catcher in the Rye, vividly shows us imagination of a teenage after the Second World War. In this novel, the writer put contradiction between American teenager material life and the lack of spiritual life after the World War II, reflected on the protagonist Holden. In the novel, Amanda Louise Holden hated the adult hypocritical world and he wanted to escape from the reality, but his weakness decided that he finally ended in failure and the collapse of the spirit. Holden is a victim of the era and the tragedy of the times. This paper tries to make a detailed and deep analysis on the tragedy of Holden in the novel.
\end{abstract}

Keywords: tragedy, The Catcher in the Rye, teenager

\section{Introduction}

Jerome David Salinger is a famous American writer. His famous novel The Catcher in the Rye is considered to be one of the classic novels of the American literature in the 20th century. Salinger's family was quite rich. When he was 15 years old, he was sent to a military boarding school in Pennsylvania by his parents. It was said that description about boarding school in The Catcher in the Rye was largely based on the background of school.

Salinger had a little fame in literary world until the publication of the novel The Catcher in the Rye made him spring into fame. For his services to literature, The Catcher in the Rye led the new trend of American literary creation. It made vacuity, emotional coldness of 50 Americans for dumping. So this period could be called "Salinger Era" beyond the definition of literature. Former US President Gorge Herbert Walker Bush called the novel as "a great work", which had inspired him.

The novel The Catcher in the Rye is the story about 16-year-old high school student Holden's experience of leaving school to Manhattan in the three days, which fully explored the heart of the teenager. And the hero's experience and thoughts caused a strong resonance in the teens, and made the readers like it. From the protagonist Holden's mantra, readers can clearly understand his aversion, which not only showed the rebellion as a teenager, but also embodied the Holden's character contradictions. Under the social background at that time, the teenager Holden was hovering between ideal and reality. The reality of the society is filled with venality, hypocrisy, and selfishness and the lack of sincere and friendly communication between people. Holden was far from victims of interpersonal relationships, and has always been squeezed out by people around. And the ideal, for Holden is a good thing, but in the end was unrealistic. About these unrealistic ideas, in the end the result was a failure. The devastation of the society, family, and school, finally Holden by his own choice expressed the hypocrisy of

JING Jing, master, lecturer, School of Foreign Languages, Changchun University.

JING Xia, bachelor, lecturer, No. 20 Junior Middle School of Siping. 
western society was ugly, brutal, cold-blooded, ruthless, exposing, and criticizing.

\section{The Writing Background of the Novel}

It was in the early $50 \mathrm{~s}$ after the World War II, the United States made a fortune in the war during this time. The material production was developing very fast after war; living standards increased rapidly and the number of the middle class was surging. But the majority of people's life became increasingly empty and scarce. In the early 50s, America government pursued Truman Doctrine and McCarthyism and contained Communism. The Cold War intensified internationally and horror of nuclear war was hanging over everyone's heart. Some people were indifferent about it and lived a chaotic life; others distained the vulgar and hypocrisy of the world, and they wanted to rebel but lacked glorious ideal and could not find a splendid way. Therefore, some America contemporary historians called the 50s and 60s of the United States as "Silent Fifties" or "Craven Fifties". So some people revolted the reality in a negative way. Salinger's protagonist was a representative.

\section{Social Response to the Novel}

In 1960, a professor in Tulsa Oklahoma was fired because of teaching the novel in the class, and then he was instated. From 1961 to 1982, The Catcher in the Rye was banned in American high school and libraries. In 1981, the novel suffered the strictest censorship in the United States, and it was also the high school required book. This was mainly derived from Holden's foul language, sex description, profanity, ignoring the ethical and moral standards of family. Holden was a negative example, rebellious, alcoholism, lying, and sexual promiscuity. Most of the protesters had not read the novel. A high school teacher Sherrie Keller was teaching the novel in the class, in the face of protests and she said that protesters and Holden were the same kind. They were all trying to be a catcher in the rye. The side effect was that people were competing to subscribe to the novel, which was unprecedented.

The novel analyzed Holden's psychological access from abhorring hypocrisy, seeking innocence to succumbing to social reality in the end. It revealed loneliness, hesitation, and pain's inner world of the American youth generation after the World War II. The novel originally got the welcome of American college students who were the generation after the World War II. But later, no matter how parents or library thought of the novel, a large number of middle school students were beginning to want to get the book to read because reading it had become the pass check into some gangs.

On the surface, Holden did not make any progress. He was smoking, drinking, falling in love disorderly, and even looking for prostitutes, which looked like a really terrible bad boy. If you just looked at the negative tendencies on the appearance, you could not really understand the kids like Holden truly. How many adults tended to use simple, brutal, and subjective approach to treat adolescents? This was causing or deepening the generation gap.

\section{The Tragedy Revealed in the Novel}

Salinger described Holden's lonely, depressed, straying life and hated, resulting in the final thoroughly disappointed and mental disorder. Holden's tragic experience reflected the Second World War brought the disaster and misfortune to the America society. It was tragic consciousness embodied in the comprehension and 
understanding of the fear of war, the choice of war, rye lonely and silent revolt.

Salinger experienced a series of life in the war and the army. When graduating from the military school, he entered the army. After more than one year's espionage training, he participated in the espionage work in Continental Europe and he joined five battles. As survivors returned from the battlefield, Salinger like his young contemporaries in the United States had experienced the baptism of war and was well versed in the crimes of war. They all bored the pain and fear that the war brought to them. The war ended the most promising generation of America and Salinger also suffered a heavy blow.

As for the protagonist, his life was shrouded in shadow of tragedy. He experienced unfortunate childhood; his cute brother died early and it caused great harm to his heart and shrouded shadow to his life. His lovely brother's figure often appeared in his mind and turned into his soul. The little brother's death brought great pain to his mother and made her extreme mental depression and if he was dismissed, it would bring a heavy blow to his mother. Whenever thought of this, his mind was tortured. He also doubted that the only beloved girlfriend Qin had sexual behavior with rogue student Stradeleta. Sister's innocence always suffered threatening by the dirty words on school wall. In Holden's eyes, all good things were fragile and perilous.

Fear is an essential component of the tragedy. The Catcher in the Rye was shrouded in the shadow of war at the beginning. At first, Holden watched the football game at distance on the hill and could see two teams rush everywhere. It frankly implied that life was a fierce struggle. The principal in Pen Xi middle school said that life was a game and you had to play by the rule.

Salinger performed the abstraction and real sense of despair successfully. He put this heavy blow in the war, human civilization after war and moral sense of tragedy transferred to an inexperienced adolescent. The protagonist Holed had no career that deserved him meanly alive but could not die heroically.

The essence of tragedy consciousness is subject to human physical mental state of the tragic survival as the reference survival to seeking truth and a special mental state of beauty. If a bomb exploded, they were blown to gore on the battlefield and Salinger was among them. It was lucky that he would die immediately and would not suffer more. But Salinger came back as a survivor from the war. Fear of the outside world war may have faded, but the spirit of fear in the inner world was difficult to fade.

America was a mess and incomprehensible world after the Second World War. Relationship between man and the world, the interpersonal relationship and the relationship between human and their own were in a state of disorder and confusion. In such a state, people were always in a state of depression and fear. Between people, any kinship, friendship, and love also contained hypocrisy and estrangement ingredients so that it showed a strong personal sense of loneliness. In The Catcher in the Rye, the author was via a disappointment, loneliness, fear, and Weary Syndrome's Holden to reflect the tragic existence of full intricate extrinsic and intrinsic contradiction people.

In Holden's eye, the adult world had been hopeless, and only the child world was a pure land full of love. It was the loneliness due to the block of mind between the adult and the child world and mentally depressed and anxious that Holden saw through people relationship. He finally thought that the gap between human minds would never be eliminated. This was also the spirit of tragedy and it led people to compromise. Confliction and compromise could reconcile the contradiction between the ideal child world and the realistic adult world. So after three days' wandering of New York, Holden decided to go to the west and pretended to be a dumb and deaf 
person there. This decision was typical of concession pessimism. Of course, we should find that Salinger used concession and forbear as a means of silent rebellion to some extent. He wanted to inspire people to think about things behind this concession phenomenon. It was a kind of deep thinking about human living conditions after war and a kind of tragic recognition about modern human diseases.

According to the view of Aristotle, tragedy aroused two basic emotions: fear and pity. Pity consists of two factors: the love and compassion for the object and regret due to the defects or pains. A beautiful thing seems to call for our sympathy and its delicate nature evokes a little compassion in our hearts. It is just this tragic effect of Salinger's The Catcher in the Rye. He chose to use the child's perspective to see real world in postwar America and stripped of the veil of harsh realities of the postwar. He was severely exposed and criticized the fear caused by the war and the breakage of modern civilization; meanwhile, he was full of close attention to the modern society and the future of human beings. He poured into his concern and sympathy to Holden who rebelled and explored in the vulgar world. He expressed infinite compassion and humanistic care to the children, which were the source of good life.

\section{Conclusion}

Holden represents the lonely American youth seeking to establish a moral code based on the transcendent values. Holden's wealthy background, however, allows him to skip over all the middle-class materialistic concerns of our society. Holden's ambition to be the "catcher in the rye" symbolizes his desire to establish a moral order. Humorous as well as honest but by no means perfect, Holden searches for some purposeful relationship, but he is not yet prepared for an adult role in society. His interest in everything stems from his youthful search for experience and freedom. His general breakdown may have been brought about by society, but it does lead him back to reality with a new awareness. Holden's new awareness, however, will not change society.

Salinger uses tragedy in the growing experience and makes Holden's life full of bitterness. When he shapes Holden, he uses a lot of proverbs, crude words, slang, and affixing language, etc. It makes the protagonist and can represent the American youth in that age. Holden is not only a character described by the author, but an image of the author himself and the representative of American teenagers in 1950s.

\section{References}

Burger, N. K. (1951). Books of the times. The New York Times.

Costello, D. P. (1959). The language in The Catcher in the Rye. American Speech, 34(3), 45-53.

Heiserman, A., \& Miller, J. E. Jr. (1956). J. D. Salinger: Some crazy cliff. Western Humanities Review, 10(2), 129-137.

Hocy, M. (1983). On the surface of discourse. London: George Allen \& Un-Win.

Mencken, H. L. (1994). American profanity. American Speech, XIX, 242.

Messent, P. B. (1990). New reading of the American novel: Narrative theory and its application. London: Macmillan.

Salinger, J. D. (1958). The catcher in the rye. Boston: Little, Brown. 